\title{
The Nature of Payment Problems in the New Zealand Construction Industry
}

Thanuja Ramachandra and James Olabode Rotimi (Construction Management Programme, Auckland University of Technology, New Zealand)

\begin{abstract}
Delay and loss of payment is a serious problem in the construction industry of many countries. These affect the cash flow of contractors which is critical to meeting their financial obligations. Payment defaults by the principal leads to insolvency of contractors and in turn other parts of the project chain. In recognition of some of these problems, most countries have established payment-specific construction industry legislation and other contractual measures to mitigate the problems, but nevertheless the problem persists. In this context, the paper examines the nature of payment problems in the construction industry in New Zealand. It is part of a larger study, that seeks solutions to payment losses in the construction industry. The study uses two approaches; an analysis of liquidators' reports, and an analysis of court cases involving payment disputes to determine the magnitude of payment problems on construction parties. The findings are presented using simple descriptive and interpretive analyses. The study finds that trade creditors are impacted negatively (payment delays and losses) by the liquidation of property developers, general construction and construction trade companies. $75 \%$ of trade creditors are unable to be paid fully by these categories of construction companies after liquidation proceedings. Liquidation proceedings take an average 18 months before they are finalised. The analysis of court cases found that $80 \%$ of payment disputes are between principals and contractors; with considerably significant percentage of disputes resulting in outright loss of payments. Only $40 \%$ of the cases are successful, in which case claimants are able to fully recover the amount in dispute. Payment losses are more prevalent in liquidation than delays and unlike in legal disputes, there is no security for those losses. The study finds that construction parties use remedies contained in the security of payment provisions within standard conditions of contract, and legislative documents.
\end{abstract}

Keywords: Payment loss, Payment disputes, Liquidation, Construction Industry, New Zealand.

\section{Introduction}

Traditionally construction project participants work first and then get paid in stages as the project work progresses. It is therefore not surprising that delayed and non-payment of invoices have become prevalent as a result of the abuse of these deferred payment privileges. There are occasional instances where project owners have made unnecessary deductions on their contractor's invoices thus causing delays to project execution and associated financial difficulties. The prevalence of this financial inappropriateness has been widely reported in notable studies that have spanned the last four decades (Banwell, 1964; Latham, 1994; Egan, 1998). Generally the construction industry has a delayed payment culture (Johnston, 1999) with payment delays becoming the major cause of disputes within the industry (Kenndy, 2005; Conlin, 1996; Heath et al., 1994; and Watts and Scrivener, 1993). Contractors and subcontractors are at the receiving end of these practices and in the UKconstruction industry for example, these group of project participants have continuously expressed their dissatisfaction towards the time lag between the receipt of their invoices to their final settlement (Odeyinka and Kaka, 2005). In New Zealand also, deferred and delayed payment of contractors' invoices are not uncommon (Gibson, 2009; Gibson, 2004). 
Failure to pay complete invoices and on time, both have many negative effects on parties to a construction contract. Payment delays and losses primarily affect the cash flow of contractors which is crucial to the success of construction projects and the survival of the industry (Ang, 2006; Singh and Lakanathan, 1992; and Peer, 1982). Frequent payment delays could lead to additional financing and transaction costs and eventually place parties down the chain in insolvency situations (Euginie, 2006).Conversely, prompt payment for completed work could be seen as a strong incentive to contractors and subcontractors to deliver quality services and to complete projects successfully (Cheng, et al., 2008).Timely and precise payment helps to develop trust and collaborative working, thereby achieving value for money for construction clients (Office of Government Commerce, 2007). Unfortunately deferment and delay of invoices are often deliberate, as deferred payment is used as a project funding mechanism by the upper tiers in a contract (Uher and Brand, 2005; Odeyinka et al., 2003).

The recognition of the nature and consequences of payment delays and losses is a key driver to the development of various legal and contractual solutions. For example there are payment provisions in standard form of contracts, bonds and guarantees, and insurance etc. Also there are enactments of construction payment specific Acts which are reviewed later. In New Zealand the Construction Contracts Act was promulgated in April 2003 to curb bad payment practices within the construction industry. This followed the repeal of the Wages Protection and Contractors Liens Act (1939) in 1987 and the 'pay when/if paid' clauses in subcontracts in 1990 (Degerholm, 2001). Cheng et al., (2008) explains that legislation is being enacted in many jurisdictions around the world, to provide security of payment to construction parties.

Nevertheless, the payment problem remains widespread within the construction industry and there are suggestions that the problem persists because of inadequacies in solutions or that the nature of the industry (many participants hence conflict of interests and disputes) promotes these sharp practices. In view of the foregoing, this paper analyses liquidator's reports and cases of construction disputes in New Zealand, to show the prevalence of payment delays and losses. It is hoped that this will indicate what remedies could be put in place to deal with the problem.

\section{Brief Literature Review}

The chain payment culture within the construction industry where payment flows from the upper to lower tiers makes the payment to lower tiers dependent on the upper tiers. Payment default or insolvency of any party affects payments to others down the chain. Even if there are no such obstacles there is often a considerable delay for those at the lower tier in receiving their payments (Khosrowshahi, 2000). Delay and losses of this nature should have reduced with the elimination or in-effectiveness of conditional payment provisions (pay-ifpaid and pay-when-paid) from most legislation. For example the Construction Contracts Act 2002 in New Zealand excluded this provision (pay-if-paid and pay-when-paid), while the United Kingdom's Housing Grants, Construction and Regeneration Act 1996 made the condition in-effective unless there is no insolvency in the contractual chain. Despite these steps, the payment problem persists (Sushani, 2005). Sushani's (2005) study found that about 16,000 contractors became nearly bankrupt because several umbrella contractors failed to honour their payment claims, even though government (project owner) had paid the umbrella contractors in full. Other literature in the UK (Reilly, 2008), Australia (Barry, 2010) and in New Zealand (The Dominion Post, 2008) present similar occurrences and recount the effects that liquidation could have on trade creditors when there is delayed payment.

As explained earlier, the recognition of the nature and consequences of payment delays and losses within the construction industry, led to the development of legal and contractual solutions in many countries. Payment provisions exist in standard form of contracts to check payment deferment and delays. Bonds and guarantees, and insurance provisions also exist 
to provide protection against the risk of non-payment in construction contracts. A major development in recent times are the enactments of construction payment specific Acts to address the payment problems in many countries (Cheng et al., 2008). One of such enactments is the Building and Construction Industry Security of Payment Act in New South Wales, Australia. The Act has helped to reduce the frequency of late payments (Brand and Uher, 2008). In New Zealand, the Construction Contracts Act (CCA) was promulgated to curb bad payment practices within the construction industry, especially following the liquidation of some large companies because of non-payment by their clients and developers (Degerholm, 2003). Prior to the CCA in New Zealand, the Wages Protection and Contractors' Liens 1939 Act was in effect and provided security to head contractors, subcontractors and workmen who perform work upon or in respect of any land by claiming a lien over the estate or interest of the owner in the land (s.21). Workmen and subcontractors were entitled to a charge over money payable under any superior contract for the work (s.21). However the repeal of the Act in 1989 left contractors and subcontractors unsecured. The removal of conditional payment provision (pay-if-paid and pay-when-paid) with the repeal of the 1939 Act, enabled subcontractors to get paid on time whether or not lead contractors are paid by the client. This protects contractors also as they may be in better position to understand the client's financial status and procure necessary security, which may be required in the event of insolvency.

In spite of these enactments, there are anecdotal evidences to suggest that the payment problem persists, albeit in different forms. Davenport (2005) commenting on the Building and Construction Industry Security of Payment Act in New South Wales, explains that the payment mechanism in that Act could lead to disputes. The disputes may derive from payment schedules such as non-issuance of payment schedules, and differences between claimed and schedule amounts. Ultimately such disputes lead to payment delays and in some cases losses to the claimants.

With reference to the CCA, New Zealand, the default provisions set out in sections 16 to 18 of the CCA only apply when a party fails to agree on the provisions of the standard forms of contract. Also the statutory payment right given in the CCA is not applicable when there is no contractual right specifying the payment. Thus the provisions in most of the standard form of contracts such as NZS3910:2003 and NZS3915:2005 supersede the provisions of the Act with regards to progress payments. Both standards provide contractors contractual rights to claim for progress and final payments. The payment procedures differ slightly. In case of progress payment, the NZS3910 requires payment to be made 17 working days after a progress payment claim (PPC) is served while NZS3915 requires the payment to be received between 10 and 15 working days respectively. The NZS3915 provision depends on whether or not there is dispute on the proposed progress payment schedule (PPPS). If no PPPS or progress payment schedule (PPS) is given, the PPC becomes PPS and the payment is made within 17 working days of the claim served. Similarly, both standards require the claimant to claim final payment within 2 months of the expiry of any defects liability period. The payment becomes due in 25 working days of receipt of a claim in NZS3910. In NZS3915 the claimant receives the payment within 22, 32, and 34 working days of payment receipt, if no disputes on proposed final payment schedule (PFPS), dispute on PFPS, and no PFPS/FPS is issued, respectively.

The CCA was implemented after the Housing Grants Construction and Regeneration Act 1996 (UK) and Building Industry Security of Payments Act 1999 (New South Wales, Australia). Unlike the Acts of the UK and NSW which introduced adjudication as statutory dispute-resolving mechanism and statutory payment rights respectively, the CCA considers both statutory payment rights and adjudication as the solution to disputes arising out from contracts. Sections 14 to 22 of the CCA provide payment provisions followed by the consequences of not making the payment as per the previous sections, in sections 23 to 24 . The Act requires the payer to respond to the claim by providing a payment schedule within

Ramachandra, T and Rotimi, J O (2011) 'The nature of payment problems in the New Zealand construction industry', Australasian Journal of Construction Economics and Building, 11 (2) 22-33 
20 working days of receipt of the payment claim. If no payment schedule is received, the payer is deemed to accept that the full amount is due and payable and must pay it forthwith. If payment is not made, the payee can claim the amount as debt due in any court. Section 25 and 72 of the CCA provides any party to a construction contract the right to refer a dispute to adjudication and enables a party to use work suspension as a measure to secure payment.

It is apparent from the foregoing that some of these enactments are not flawless and that payment problems could be experienced within the construction industry. The current paper therefore investigates the issue by studying liquidators' reports and High Court cases. Information obtained would give an indication of the nature of the payment problem so that remedial measures could be explored for future construction projects.

\section{Research Method}

This study is part of a wider research programme that is undertaken in New Zealand to provide solutions to payment losses in the construction industry. The study uses two approaches; an analysis of liquidators' reports, and an analysis of court cases involving payment disputes to determine the existence and magnitude of payment problems on construction parties.

The first data set involved liquidators' reports for three categories of construction companies for which the liquidation proceedings were completed during the 2007 to 2010 period. Information on a total of 80 liquidated companies were obtained, but the analysis is based on 65 companies with the dataset required for this study. A primary focus is information on payment delays and losses to trade creditors as these could be used as proxies to construction parties. Other information such as the time taken to complete the liquidation process; amount paid/not paid to trade creditors are also used to determine the magnitude of payment delays and losses.

The second data set involved reports of construction disputes filed in the High Court from 2008 to 2010. Thus a total of 40 payment-related cases filed in the High Court during the period were used for the analyses. The cases were analysed to ascertain the status of payment delays and losses as determined from the courts' final judgements. For example if the plaintiff/claimant is a contractor and the judgement is in favour of the claimant, this paper assumes that the proceedings would still have resulted in delays and in some situations a loss to the claimant.

It is hoped that these data sources would yield clarity into the status of the payment delays and losses experienced by construction industry participants. A document review on the data set was also undertaken to determine how some of these payment problems were resolved. The findings are presented using simple descriptive and interpretive analyses for clarity and ease of undestanding.

\section{Research Findings}

\section{Analyses of Construction Liquidation Reports}

The following paragraphs discuss the result of the information extracted from liquidators' reports for the period 2005 to 2009. Information collated from the liquidators reports included: the category of construction companies in liquidation, the amount owed by the companies and the time it took to finalise the liquidation proceedings. The resulting analysis was based on simple frequency counts of these set of information.

The liquidators' reports show that there are three main categories of construction companies that go into liquidation (general construction, property development and construction trade services) in New Zealand. Table 1 gives a breakdown of the number and percentage of the 
three construction categories which were used for the analyses. Each of these categories owes secured, preferential, and unsecured trade creditors. The study found that secured creditors are protected with the retention of title claims or their secured interest over the goods or equipment supplied to the company in liquidation; while preferential creditors get paid out of liquidation proceeds as they rank the highest amongst all creditors. It is the unsecured creditors that are mostly left with little or nothing after liquidation proceedings.

Table 1 also gives a breakdown of the amounts owed to trade creditors (and the corresponding amount owed within each category) by the three categories of companies in liquidation within the period. The sums of money owed to trade creditors are classified, and range from below $\$ 10,000$ to above $\$ 1,000,000$. The classification of the amounts owed was done for ease of representation.

\begin{tabular}{|c|c|c|c|c|c|}
\hline $\begin{array}{l}\text { Construction } \\
\text { category }\end{array}$ & $\begin{array}{l}\text { Number in } \\
\text { each } \\
\text { category }\end{array}$ & $\begin{array}{c}\text { Percentage } \\
\%\end{array}$ & Amount Owed (NZ\$) & Frequency & $\begin{array}{c}\text { Percentage } \\
\%\end{array}$ \\
\hline \multirow{4}{*}{$\begin{array}{c}\text { General } \\
\text { Construction } \\
\text { Companies }\end{array}$} & \multirow{4}{*}{27} & \multirow{4}{*}{42} & Above $1,000,000$ & 4 & 15 \\
\hline & & & $500,000-1,000,000$ & 5 & 18 \\
\hline & & & $100,000-500,000$ & 10 & 37 \\
\hline & & & Below 100,000 & 8 & 30 \\
\hline \multirow{5}{*}{ Property Developers } & \multirow{5}{*}{22} & \multirow{5}{*}{34} & Above 200,000 & 2 & 9 \\
\hline & & & $100,000-200,000$ & 4 & 18 \\
\hline & & & $50,000-100,000$ & 1 & 4 \\
\hline & & & $10,000-50,000$ & 3 & 14 \\
\hline & & & Below 10,000 & 12 & 55 \\
\hline \multirow{3}{*}{$\begin{array}{c}\text { Construction Trade } \\
\text { Services }\end{array}$} & \multirow{3}{*}{16} & \multirow{3}{*}{24} & Above 200,000 & 3 & 19 \\
\hline & & & $100,000-200,000$ & 4 & 25 \\
\hline & & & Below 100,000 & 9 & 56 \\
\hline Totals & 65 & 100 & & & \\
\hline
\end{tabular}

Table 1 Amount owed by construction companies in liquidation

From the Table 1, it is observed that the value of the amount owed to trade creditors by general construction companies is the largest of the three categories. This is obvious considering that this group includes small to fairly medium scale construction firms with a higher level of turnover than the other two categories. The largest percentage $(37 \%)$ of companies in the general construction business owed their trade creditors between $\$ 100,000$ and $\$ 500,000$ when they went into liquidation. Followed by another $30 \%$ owing less than $\$ 100,000$. Further examination of the liquidators' reports reveal that on average the amount owed to trade creditors by this category of construction companies were about $78 \%$ of the total sum owed to unsecured creditors. This value is indicative of the negative impact that liquidation of this category of construction companies can have on other parties in the chain.

On the other hand, property developers that went into liquidation largely (55\%) owed their creditors less than $\$ 10,000$ during the period. Comparatively the value owed is less than general construction companies because these property developers were mostly involved in residential construction works. Further analyses reveal that of the property developers that owed less than $\$ 10,000,60 \%$ owed between $\$ 1,000$ and $\$, 5000$. On overage the amount 
owed to trade creditors by this category of construction company is $20 \%$ of the total owed to their unsecured credtiors. Compared to other construction categories this amount seem insignificant.

Finally Table 1 presents information on the amount owed to trade creditors by companies in the construction trade services category. The breakdown shows that the amount owed ranges from below $\$ 100,000$ to above $\$ 200,000$. The largest percentage (56\%) of companies owed less than $\$ 100,000$. A further analysis of the $56 \%$ that owed below $\$ 100,000$ shows that $67 \%$ owed between $\$ 50,000$ to $\$ 100,000$. Upon further examination of the reports, it was observed that on average, the amount owed to trade creditors were $70 \%$ of amount owed to total unsecured creditors by this category. This is considerably significant, although lower when compared to companies in general construction.

There was further investigation into the liquidators' reports to determine how well these categories of companies honour payment obligations after liquidation proceedings. The reports show that all the companies in the general construction category were unable to pay their trade creditors after the liquidation proceedings. Liquidated property development companies fared slightly better but with one company (out of 22 ) that partly paid (11.89 cents per dollar) to its creditors. $17(77 \%)$ of the property developers could not pay their creditors and the remaining had either no trade creditors or did not disclose the amount they owe their trade creditors. Of note is that the only property development company that made partial payment to its creditors took 6 months to pay after the liquidation proceedings. Evidently the time lag between the liquidation proceeding and final settlement is an unnecessary delay that could not augur well for the creditors.

In the construction trade services category, one (out of 16) company paid its trade creditors fully, about $20 \%$ paid pro rata (20 cents per dollar), and $75 \%$ (12 out of 16 ) could not pay their creditors at all. Further investigation show that settlement of trade creditors took an average of 18 months since the commencement of liquidation proceedings to be finalised.

The foregoing provides evidence of both payment delays and losses when construction companies are liquidated. Although there is no clear indication of the delays and losses experienced by individual construction participants (head contractors, subcontractors, subsubcontractors etc), or which tier (upper or lower) is affected in liquidation. It is however clear that trade creditors are at the receiving end in any liquidation proceeding. In the following section, construction disputes are analysed in the hope that this will permit a determination of the construction parties affected by payment delays and losses.

\section{Analyses of Legal Disputes in Construction}

The result of the information extracted from construction disputes which were filed in the High Court between 2008 to 2010 in New Zealand, are presented in the following paragraphs. There were 40 legal disputes which were heard or transferred to the High Court within the period. The cases relate to payment disputes between parties to construction contracts (principal, lead contractors and sub contractors). A breakdown of the cases is presented in Table 2. The table provides information on the parties and the amounts in dispute, the nature of the payment in dispute and the final status (in terms of delays and losses). On observation, the table shows that nearly $82 \%$ (33 out of 40) of the cases considered are payment disputes between principals and contractors; while the remaining $8 \%$ and $10 \%$ of the disputes are between principals and subcontractors; and contractors and subcontractors respectively.

For legal disputes between principals and contractors, $60 \%$ of the times the principals were the plaintiff while in the remaining $40 \%$, the plaintiff were the contractors. This would suggest that payment delays and losses are more likely to be among principals, and contractors than with subcontractors. Analysis of the cases reveal that the disputes deal primarily with the validity of progress and final payment claims, claims for variation cost, variation between 


\begin{tabular}{|c|c|c|c|c|c|}
\hline No. & $\begin{array}{l}\text { Plaintiff } \\
\text { (P/C/SC) }\end{array}$ & $\begin{array}{l}\text { Defendant } \\
\text { (P/C/SC) }\end{array}$ & $\begin{array}{l}\text { Nature of } \\
\text { payment in } \\
\text { dispute }\end{array}$ & $\begin{array}{l}\text { Amount } \\
\text { Claimed } \\
\text { (NZ\$) }\end{array}$ & Status of payment in final judgement/decision \\
\hline 1 & $\mathrm{P}$ & SC & FP & $32 \mathrm{k}$ & Improper statutory demand - Loss to subcontractor. \\
\hline 2 & SC & $\mathrm{C}$ & FP & $1,184 \mathrm{k}$ & $\begin{array}{l}\text { Court awarded subcontractor } \$ 327 \mathrm{k} \text { - Delay and loss to } \\
\text { subcontractor. }\end{array}$ \\
\hline 3 & $\mathrm{P}$ & $\mathrm{C}$ & FP & $442 \mathrm{k}$ & Claim was paid in full - Delay to contractor. \\
\hline 4 & C & SC & FP & $33 \mathrm{k}$ & Statutory demand is set aside - Loss to subcontractor. \\
\hline 5 & C & $\mathrm{P}$ & FP & $72 \mathrm{k}$ & Principal's statutory demand was set aside - Loss to Principal. \\
\hline 6 & C & SC & FP & $345,395 k$ & $\begin{array}{l}\text { Application to set aside the statutory demand was withdrawn, } \\
\text { contractor is entitled to pay subcontractor - Delay. }\end{array}$ \\
\hline 7 & $P$ & C & FP & $110 k$ & $\begin{array}{l}\text { Application to stay liquidation proceeding was dismissed } \\
\text { Loss to Principal. }\end{array}$ \\
\hline 8 & $\mathrm{P}$ & $\mathrm{C}$ & FP & $1,324 \mathrm{k}$ & Bankruptcy application is adjourned - Likely loss to contractor. \\
\hline 9 & $P$ & C & FP & $28 \mathrm{k}$ & $\begin{array}{l}\text { Caveat for non-payment is removed and the amount is held in } \\
\text { trust account pending resolution - Delay to contractor. }\end{array}$ \\
\hline 10 & $\mathrm{P}$ & $\mathrm{C}$ & $\mathrm{FP}$ & $109 \mathrm{k}$ & Contractor was paid in full but experiences a delay. \\
\hline 11 & $\mathrm{P}$ & SC & PP & $47,000 \mathrm{k}$ & Case referred to adjudication. \\
\hline 12 & C & $\mathrm{P}$ & PP & Undisclosed & Technically invalid payment claim- Loss to contractor. \\
\hline 13 & $\mathrm{P}$ & C & PP & $190 \mathrm{k}$ & Unresolved. \\
\hline 14 & C & $P$ & PP & $219 \mathrm{k}$ & $\begin{array}{l}\text { Contractor has no caveatable interest in the land - Likely loss } \\
\text { to contractor. }\end{array}$ \\
\hline 15 & $\mathrm{P}$ & C & PP & $37 \mathrm{k}$ & Payment claim is not valid - Loss to contractor. \\
\hline 16 & $\mathrm{P}$ & C & PP & $53 \mathrm{k}$ & Contractor was paid in full - Delay to contractor. \\
\hline 17 & C & $P$ & PP & $511 \mathrm{k}$ & $\begin{array}{l}\text { Contractor was successful partially and paid } \$ 178 \mathrm{k} \text { and lost } \\
\$ 332 \mathrm{k} \text { - Delay and loss to contractor. }\end{array}$ \\
\hline 18 & $\mathrm{C}$ & $\mathrm{P}$ & PP & $22 \mathrm{k}$ & Both parties were successful - Dispute resolved. \\
\hline 19 & C & $\mathrm{P}$ & PP & $205 k$ & $\begin{array}{l}\text { Claims were valid, contractor was awarded full amount but } \\
\text { experienced delay. }\end{array}$ \\
\hline 20 & C & $\mathrm{P}$ & PP & $97 \mathrm{k}$ & Contractor remains as unsecured creditor - Loss to contractor. \\
\hline 21 & $P$ & C & PP & $76 k$ & $\begin{array}{l}\text { Court awarded contractor } \$ 57 \mathrm{k} \text { - a delay and loss to } \\
\text { contractor. }\end{array}$ \\
\hline 22 & $P$ & C & PP & $466 k$ & $\begin{array}{l}\text { Statutory demand is not set aside, contractor is to be paid } \\
\text { Delay to contractor. }\end{array}$ \\
\hline 23 & $\mathrm{P}$ & C & PP & $139 \mathrm{k}$ & Contractor is paid in full but experienced a delay. \\
\hline 24 & $\mathrm{P}$ & SC & PP & $766 \mathrm{k}$ & Statutory demand was set aside - Loss to subcontractor. \\
\hline 25 & C & $\mathrm{P}$ & PP & $78 \mathrm{k}$ & $\begin{array}{l}\text { Case referred to adjudication - Likely outcome is delay to } \\
\text { contractor. }\end{array}$ \\
\hline 26 & C & $P$ & PP & Undisclosed & $\begin{array}{l}\text { Contractor discontinued the court proceedings - Dispute } \\
\text { resolved. }\end{array}$ \\
\hline 27 & $\mathrm{P}$ & C & PP & $35 \mathrm{k}$ & Contractor was paid in full but experiences a delay. \\
\hline 28 & $P$ & C & PP & $13 \mathrm{k}$ & $\begin{array}{l}\text { Court ordered contractor to pay Principal - Contractor lost the } \\
\text { claim of } \$ 19 \mathrm{k} \text { and pay } \$ 12 \mathrm{k} \text {; delay to principal. }\end{array}$ \\
\hline 29 & $\mathrm{P}$ & $\mathrm{C}$ & PP & $157 \mathrm{k}$ & Contractor was paid in full but experiences delay. \\
\hline 30 & C & $\mathrm{P}$ & PP & $11 \mathrm{k}$ & Dispute remains unresolved - Likely delay or loss to contractor. \\
\hline 31 & C & $\mathrm{P}$ & PP & $246 \mathrm{k}$ & $\begin{array}{l}\text { Contractor awarded partially } \$ 79 \mathrm{k} \text { pending further order } \\
\text { Delay and loss to contractor. }\end{array}$ \\
\hline 32 & $P$ & C & PP & $28 \mathrm{k}$ & $\begin{array}{l}\text { Application to set aside summary judgement was successful; } \\
\text { Principal as trustee not the legal entity entitled to payment } \\
\text { Loss for the party who has done the work. }\end{array}$ \\
\hline 33 & $P$ & C & OP & $282 \mathrm{k}$ & $\begin{array}{l}\text { Bankruptcy notice is accepted, Contractor is to be paid } \$ 322 \mathrm{k} \\
\text { as per adjudicator's determination - Delay to contractor. }\end{array}$ \\
\hline 34 & C & $\mathrm{P}$ & Retention & $33 \mathrm{k}$ & Contractor was paid in full but experiences delay. \\
\hline 35 & C & $\mathrm{P}$ & OP & $13 \mathrm{k}$ & $\begin{array}{l}\text { Court awarded contractor } \$ 13 \mathrm{k} \text { plus the costs of preparing for } \\
\text { and appearing at the summary judgment hearing related to } \\
\text { payment claim of } \$ 27 \mathrm{k} \text { - Delay. }\end{array}$ \\
\hline 36 & C & SC & OP & $123 \mathrm{k}$ & $\begin{array}{l}\text { Costs awarded to contractor in dispute due to non-issuance of } \\
\text { payment schedule for } \$ 123 \mathrm{k} \text { is defended - Delay to } \\
\text { subcontractor. }\end{array}$ \\
\hline 37 & $\mathrm{P}$ & C & OP & $112 k$ & $\begin{array}{l}\text { Statutory demand for the payment was set aside by consents } \\
\text { neither loss nor delay to the contractor. }\end{array}$ \\
\hline 38 & C & $\mathrm{P}$ & OP & $280 \mathrm{k}$ & $\begin{array}{l}\text { Contractor's application to enter the charging order is } \\
\text { dismissed as only District Court could enter a charging order - } \\
\text { Likely loss and delay to contractor. }\end{array}$ \\
\hline 39 & $P$ & C & OP & $1,000 \mathrm{k}$ & $\begin{array}{l}\text { Principal's interim relief application is declined - Likely delay to } \\
\text { contractor. }\end{array}$ \\
\hline 40 & $P$ & C & OP & Undisclosed & $\begin{array}{l}\text { Application for adjournment was declined - Contractor to be } \\
\text { paid but delayed. }\end{array}$ \\
\hline
\end{tabular}

Table 2 Summary of construction payment disputes

Ramachandra, T and Rotimi, J O (2011) 'The nature of payment problems in the New Zealand construction industry', Australasian Journal of Construction Economics and Building, 11 (2) 22-33 
claimed and schedule amount, non-payment due to defective and incomplete work, nonissuance of payment schedule, etc. Thus for ease of analyses, this paper has classified the payment claims into three: final (FP), progress (PP) and other payments (OP). Other payment claims includes claims which are not defined as progress or final payment; and they include payment of retention sums, claim for costs incurred in court proceedings related to the payment claim and schedule.

The result show that 22 cases out of 40 (55\%) studied were related to progress payments; $25 \%$ related to final payments and the remaining $20 \%$ are other payments. Therefore it would seem that it is the progress and final payments that are more likely to be delayed and lost by construction participants. A breakdown showing the magnitude of the sums in dispute are depicted in figure 1. The figure shows that most of the claims (46\%) are in the less than $\$ 100,000$ category. The second highest number of claims (40\%) is between $\$ 100,000$ and $\$ 500,000$. The amount claimed in $11 \%$ of the cases was above $\$ 1,000,000$ while in $3 \%$ of the cases the claims were between $\$ 500,000$ and $\$ 1,000,000$.

Table 2 gives a comparison of the amounts in disputes (column 5) with those awarded in the final judgement (column 6). This shows that there is a high probability (risk) that construction payments will either be delayed, paid partly/fully or both. Payment delays are obvious in court cases because the cases would have been through an adjudication process, the District Court enforcement, and subsequently to the High Court for appeal. Though, some cases could be filed directly at the High Court without necessarily going through an adjudication process. In reporting the figure, the paper therefore assumes that whether a claimant is paid fully or partially, since it was referred to the High Court, the project would have been delayed. Payment loss is assumed to have been experienced by a claimant when it loses the claim or was not paid by the defendant. The status of payment was classified as likely delay or loss if it was unresolved, pending further decision or determination.

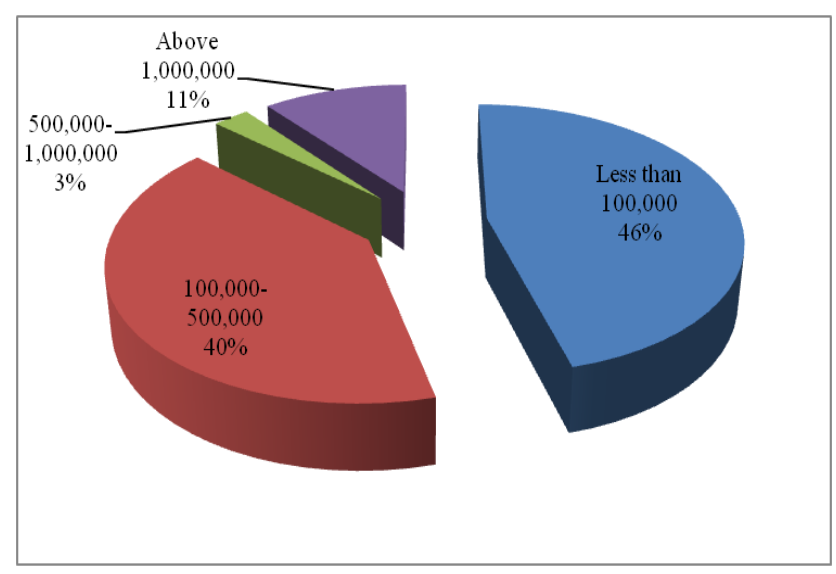

Figure 1 Distribution of amount claimed in disputes

Table 3 provides the summary of payment status in final judgement and indicates that, in $40 \%$ of the cases claimants were paid fully but experienced delay in getting paid. In another $10 \%$ claimants were partially paid, experienced delay in the process while also losing the amount that was not paid. It was observed that $25 \%$ of the claimants lost their case for reasons traceable to their actions or inaction. For example some of the claimants failed to comply with contractual obligations; submitted invalid payment claims and statutory demands; and provided inappropriate payment schedules. For the $25 \%$ of claimants who lost their cases, the amount lost was mostly less than $\$ 100,000$.

A further $20 \%$ identified in the study are those companies that are likely to be delayed or lose money, because these few cases were unresolved and referred back to adjudication. 
The remaining $5 \%$ shown in the table refer to cases in which both parties (claimant and defendant) came to an agreement and the disputes were consequently resolved.

On evaluation of the cases, it was found that it took an average of 4 days to arrive at judgements from the date the cases were heard in the High Court. 19 of the cases (out of 40) were filed in the High Court following the enforcement of Adjudicator's determination at District Courts. Adjudication usually takes up to 6weeks from the commencement of the process.

Generally, irrespective of adjudication or court decisions, delay to payment requests would have been experienced by parties to a contract when a legal dispute is involved. The forgoing provides an insight into construction payment delays and losses and show that these are prevalent. It gives an indication that some solutions need to be sought. Therefore the next section reviews the strategies that are used in construction liquidation and construction disputes to tackle the payment problems.

\begin{tabular}{|l|c|c|}
\hline \multicolumn{1}{|c|}{ Payment status } & No of cases & $\%$ \\
\hline Paid fully - Delay & 16 & 40 \\
\hline Paid partially - Loss \& delay & 4 & 10 \\
\hline Loss & 10 & 25 \\
\hline Likely loss or delay & 8 & 20 \\
\hline Other & 2 & 5 \\
\hline Total & $\mathbf{4 0}$ & $\mathbf{1 0 0}$ \\
\hline
\end{tabular}

Table 3 Status of payment disputes

\section{Strategies Used to Tackle Payment Delays and Losses}

Further analyses of the 40 legal disputes which were heard or transferred to the High Court cases between 2008 and 2010 was undertaken to determine the different strategies used by claimants to protect against delays and losses. The investigations reveal that legal and contractual provisions available in the CCA and standard forms of contracts (such as NZS3910:2003 and NZS3915:2005) were employed by the claimants. The CCA provisions were used in more than $50 \%$ (21 out of 40 ) of the disputes while another $20 \%$ used standard form of contracts.

Other strategies used include the placing of a charging order or caveat registration, bankruptcy and liquidation proceedings etc, as a remedy for non-payment. Section 29 of the CCA allows a party to obtain approval for issuing a charging order against a site owned by the respondent (in this case the project owner). The dispute records show that in few cases (4 out of 40 cases) claimants have sought for a charging order to mitigate non-payment by respondents and these were approved by the Adjudicator. Subsequently a charging order was placed over the owners' properties.

Caveats are another strategy used to tackle delays and losses in a construction contract. A caveat is a notice which is registered against a title for any party to be aware that a claim is being made and sought. Caveats are used by persons who wish to protect an interest in land by preventing the registered proprietor from disposing of the land or dealing with it in a way that would affect the caveators' rights and interests. The administration of caveats is contained in the New Zealand Land Transfer Act 1952. In one of the 40 cases the claimant (developer) lodged a caveat against the title of the land to recover payment due from owner. In another situation a project owner applied to the Court for a removal of the caveat lodged by the contractor over his land. 
Finally the dispute records show that in two cases (4\%) the principal (project owner) submitted an application to set aside the bankruptcy notices issued to them. This was made after an order to pay their contractors. In few other cases, some claimants' lodged liquidation proceedings to recover the amount claimed, which was subsequently appealed by the respondents to stay the liquidation proceedings. In both cases the applications were dismissed. These few cases give an indication that bankruptcy notice and liquidation proceedings could be used as a last resort to recover payments from project owners and debtors.

\section{Conclusions}

This paper has analysed liquidators' reports and construction payment dispute cases filed in the High Court, to determine the nature of payment losses and delays in the New Zealand construction industry. In addition it reviewed some of the strategies used to deal with delays and losses by parties in construction contracts.

The results reveal that a significant percentage of construction companies went into liquidation within the period of analyses. This caused losses and delays to their trade creditors. For example, $37 \%$ of general construction companies owed between $\$ 100,000$ and $\$ 500,000$ while another $30 \%$ owed less than $\$ 100,000$. More than $50 \%$ of construction trade service companies owed less than $\$ 100,000$ whilst $55 \%$ of property developers owed less than $\$ 10,000$. The study has shown that above $75 \%$ of trade creditors are unable to be paid fully by the three categories of construction companies after liquidation proceedings. Liquidation proceedings take an average 18 months before being finalised. The magnitude of losses experienced by trade creditors vary widely depending on the category of construction companies that are being liquidated. It could be concluded that liquidation of companies most often result in payment losses and delays and there seems to be little security for payment losses in insolvencies.

The above conclusions are corroborated by the results obtained from the investigation of payment disputes heard in the High Courts. The results provide further evidence that payment delays and losses are prevalent within the industry. Disputes relating to progress and final payments account for $80 \%$ of the High Court cases analysed. The study found that upon Court decisions, only $40 \%$ of the cases are successful in which case the claimants recovered all the money in dispute, while the remaining cases are either partially successful or unsuccessful. Disputes mainly emanated from provisions in legal and contractual instruments such as those outlined in the CCA and other standard conditions of contracts in New Zealand. Therefore as well as providing protection from delays and losses, some of the procedural requirements in these documents may become sources of disputes that could also cause delays and losses to the parties in dispute.

Finally the study reveals that several strategies for securing payments are being used within the New Zealand construction industry. Some of these include: the placing of charging orders and registering caveatable interest over properties, lodging bankruptcy and liquidation proceedings, holding money in trust account, direct payment by sureties. Further investigations into the success of these strategies would be useful in future research studies.

\section{Acknowledgement}

The authors acknowledge the contributions of Daniel Datt Suresh for helping with the extraction of the required information from the High Court case files.

\section{References}

Ang, S. S. (2006) Payment issues - The present dilemmas of Malaysian construction industry (Unpublished MSc thesis), Universiti Teknologi Malaysia, Johor Bahru, Malaysia 
Banwell, H. and Ministry of Public Building and Works (1964) The placing and management of contracts for building and civil engineering work: report of the committee: HMSO, London

Barry, S. (2010) 25 firms follow builder into liquidation, Retrieved 17 Feb 2010 from http://www.abc.net.au/news/stories/

Brand, M. C., and Uher, T. E. (2008) 'Review of the performance of security of payment legislation in New South Wales', Paper presented at the RICS Construction and building research conference COBRA, 4-5 September, Dublin Institute of Technology, Ireland

Cheng, T., Soo, G., Kumaraswamy, M., and Jin, W. (2009) 'Security of Payment for Hong Kong Construction Industry - Workable alternatives and suggestions', Building Journal Hong Kong China, 60-77

Conlin, J.T., Langford, A.D. and Kennedy, P. (1996) 'The Relationship between Construction Procurement Strategies and Construction Contract Disputes', In Taylor, R.G. (ed.) Proceedings of CIB W92 Symposium: North Meets South: Developing Ideas, University of Natal, South Africa

Construction Contracts Act 2002, no. 46, The Parliament of New Zealand

Davenport, P. (2005) 'Security of payment - the pendulum has swung too far', Australian Construction Law, 101 (March/April), 36-40

Degerholm, P. (2001) 'Construction Contracts Bill 2001', Fortune Manning, July (54)

Degerholm, P. (2003) Managing Contractors' Cashflow, Auckland: Rawlinsons Media Limited

Egan, J. (1998) Rethinking Construction: The Report of the Construction Task Force DETR, London

Euginie, L. (2006) 'Curing the Ills of Non-Payment in the Construction Industry - the Singapore Experience', 8th Surveyors' Congress, Kuala Lumpur: ISM

Gibson, A. (2004, 18 November) Win for builder in court, New Zealand Herald, Retrieved from http://www.nzherald.co.nz/business/news/article.cfm?c_id=3\&objectid=3611310

Gibson, A. (2009, 22 April) Fletcher wins judgement in Melview case, New Zealand Herald, Retrieved from http://www.nzherald.co.nz/business/news/

Heath, B.C., Hills, B. and Berry, M. (1994) 'The nature and origin of conflict within the construction process', in Proceedings of CIB TG15 Meeting in Kentucky, USA, ed. Fenn, P. CIB Publication 171

Johnston S (1999) Debts and Interest in the Construction Industry: A guide to the late payment of commercial debts (interest) Act 1998, Thomas Telford Limited, London

Kennedy, P. (2005) 'Statistics and trends in statutory adjudication in the UK since 1998', Paper presented at the meeting of the International forum on construction industry payment Act and Adjudication, Kuala Lumpur, Malaysia, 13-14 September

Khosrowshahi, R. (2000) 'A radical approach to risk in project financial management', Proceedings of the $16^{\text {th }}$ Annual ARCOM conference, Glasgow Caledonian University, September 6-8, 547-556

Land Transfer Act 1952 No 52 (as at 01 August 2008), Public Act 1952, s 136-137

Latham, M. (1994) Constructing the team: final report of the government/industry review of procurement and contractual arrangements in the UK construction industry: HMSO: London

NZS 3910:2003 Conditions of Contract for Building and Civil Engineering Construction, Standard New Zealand, Wellington: Standard Council

NZS 3915:2005Conditions of Contract for Building and Civil Engineering Construction, Standard New Zealand, Wellington: Standard Council 
Odeyinka, H. A. and Kaka, A. (2005) 'An evaluation of contractors' satisfaction with payment terms influencing construction cash flow', Financial Management of Property and Construction, 10 (3), 171-180

Odeyinka,H.A., Kaka A. and Morledge, R. (2003) 'An evaluation of construction cash flow management approaches in contracting organizations', In Greenwood, D. (ed.) Proceedings of $19^{\text {th }}$ Annual ARCOM conference, University of Brighton, September 3-5, 33-41

Office of Government Commerce. (2007) Guide to best 'Fair Payment' practices, Retrieved 15 January 2010, from http://www.ogc.gov.uk/documents/

Peer, S. (1982) 'Application of cash flow forecasting models', Journal of the Construction Division ASCE, 108, 226-232

Reilly, J. (2008) Top luxury developer forced into liquidation, Retrieved 3 June 2010, from http://www.independent.ie/national-news/

Singh, S. and Lakanathan, G. (1992) 'Computer-based cash flow model', In Proceedings of the $36^{\text {th }}$ Annual Transactions of the American Association of Cost Engineers - AACE, USA, No.R.5.1-R.5.14

Sushani, A. (2005) No joy for the small builders, The Star online, 8 May 2005, Retrieved from http://thestar.com.my/news

The Dominion Post (2008, 29 June) Not a cent for builder's creditors: Big claims, few assets, Retrieved from http://findarticles.com/p/news-articles/

Uher, T. E., and Brand, M. C. (2005) 'Analysis of adjudication determinations made under security of payment legislation in New South Wales', International Journal of Project Management, 23 (6), 474-482

Watts, V. M. and Scrivener, J. C. (1993) 'Review of Australian Building disputes settled by litigation', Building Research Information, 21 (1), 59-63 